\title{
Share Price Reaction to Dividend Announcements: Empirical Evidence on the Signaling Model from the Oslo Stock Exchange
}

\author{
John Capstaff \\ University of Strathclyde, U.K. \\ Audun Klæboe \\ Nordea Bank, Norway \\ Andrew P. Marshall \\ University of Strathclyde, U.K.
}

This study tests the signaling theory of dividends by investigating the stock price reaction to dividend announcements on the Oslo Stock Exchange (OSE), and subsequent changes in the cash flows of the firms involved. This paper adds to existing evidence by examining the role of dividends in a market where the corporate ownership structure is notably different from the U.S. and the U.K., and where the motivation to use dividends as a signaling mechanism appears to be stronger. The results indicate significant abnormal stock returns are associated with announcements of dividend changes. The results are robust to alternative models of dividend expectations, after controlling for the impact of earnings announcements, and are consistent across sub-periods in the sample. The stock market reaction is most pronounced for large, positive dividend announcements that are followed by permanent cash flow increases. This evidence provides modest support for the signaling theory of dividends in Norway, but it does not support the proposition that corporate ownership structure is an important influence on the use of dividends as a signaling mechanism (JEL: G32; G35).

Keywords: dividend announcements, Oslo stock exchange, signaling.

\footnotetext{
${ }^{*}$ We wish to thank Mr. Frode Mæland Strand at the Norwegian School of Economics and Business Administration, for providing additional data from the Oslo Stock Exchange and Martin Kemmitt for data collection. We also wish to thank two anonymous reviewers for their very helpful and insightful comments on earlier drafts. Any remaining errors are the responsibility of the authors. The views do not represent those of Nordea Bank.
}

(Multinational Finance Journal, 2004, vol.8, no.1 \& 2, pp. 115-139)

(C) Multinational Finance Society, a nonprofit corporation. All rights reserved.

DOI: $10.17578 / 8-1 / 2-4$ 


\section{Introduction}

This study investigates the market reaction to dividend announcements in Norway and assesses whether this can be explained by signaling theory. Signaling theory holds that dividends are used to signal management's expectations of a permanent change in the future earnings of the firm, and the market reacts by revaluing the firm's shares. A market reaction could result from either new value relevant information in the dividend, or from a change in agency costs. To confirm the signaling theory of dividends, therefore, it is necessary that the market reaction is followed by a permanent change in future earnings (or cash flows), in the same direction as the dividend change.

Norway is an interesting environment in which to test the signaling hypothesis due to its corporate ownership structure that serves to reduce agency costs and increase information asymmetries relative to the more intensively researched U.S. and U.K. markets. The motivation for managers to use dividends as a signaling mechanism may be stronger in such an environment. A test of the signaling hypothesis in Norway could, therefore, shed light on the importance of ownership structure when interpreting evidence on the market reaction to dividend changes. The clear dividend payment process and the neutral tax system in Norway reduce the scope for 'noise' in the results.

Using data from 1993 to 1998 we find that significant abnormal stock market returns are associated with announcements of both dividend increases and dividend decreases. The results are robust to different models of dividend expectations, after controlling for the impact of different earnings announcements, and are consistent over sub-periods in the sample. The stock market reaction is more pronounced for larger dividend changes, and for positive dividend announcements that are followed by permanent cash flow increases. We interpret these results as evidence that dividend changes convey new information to market participants, and also as evidence, though less compelling, of the dividend signaling theory. The evidence from Norway does not, however, support the proposition that corporate ownership structure is an important influence on the use of dividends as a signaling mechanism.

The remainder of the paper is organized as follows. Section II discusses the previous literature, the motivation for this study, and hypotheses to be tested. Section III describes the data, the classification of stocks according to dividend announcements, and the testing methods 
employed. Section IV discusses the empirical results. Section V provides some additional tests that examine the robustness of the results and testing methods employed in the study. Finally, the conclusions are provided in section VI.

\section{Literature Review and Hypothesis Development}

The extensive literature on the signaling properties of dividends from Bhattacharya (1979) to Benartzi et al. (2002) generally reports significant stock market reactions in the same direction as the announced dividend changes. ${ }^{1}$ These findings are consistent either with changes in agency costs or with new information about corporate value conveyed by the dividend changes. However, evidence that supports the dividend signaling theory is scarce. Allen and Michaely (2003, p.73) express the view that, "The overall accumulated evidence does not support the assertion that dividend changes convey information about future earnings", whilst La Porta et al. (2000) provide extensive evidence that agency models are the key to understanding dividend policies around the world. One possible reason for the above findings is that the corporate ownership structure, particularly in the U.S. and U.K. markets, may curtail the use of dividends as a signaling mechanism. This paper aims to add to the evidence by examining the role of dividends in the Norwegian market where the corporate ownership structure is notably different, and where the motivation to use dividends as a signaling mechanism may be stronger.

The dividend system in Norway is relatively simple. Firms pay only one dividend per year, and cash is the only admissible form of disbursement to shareholders, which almost exclusively takes the form of dividends. Bohern et al. (1997) find that stock repurchases are exceptional, and that Norwegian firms pay lower dividends in comparison to the U.K. and U.S. measured relative to both earnings and share price. ${ }^{2}$ One partial explanation is that unlike the U.S. and U.K. markets Norwegian corporate law puts a specific quantifiable ceiling on the amounts of dividends a firm can pay in any given year.

1. See also the large number of papers from Pettit (1972) to Koch and Shenoy (1999).

2. Norwegian firms typically pay less than one third of their profits to shareholders and the dividend yield in Norway is lower than in most other European stock markets; Oslo Stock Exchange (1998). 
The ownership structure of Norwegian firms is different from the U.S. and the U.K. where it is relatively dispersed. In Norway, inside share ownership was around $15 \%$, on average, over the period of this study from 1993-1998 (Norwegian Registry of Securities, 1999). ${ }^{3}$ Ownership concentration is also high in Norway. Bohern et al. (1997) report that between 1984 and 1994, the three largest owners held, on average, $41 \%$ of firms' shares. Comparable figures for U.K. and U.S. respectively are $21 \%$ and $25 \%$; see Prowse (1995). ${ }^{4}$ The ownership structure has implications for agency costs. The agency argument is that dividends are good news because they reduce agency costs. Ceteris paribus, higher dividend firms require more external finance and will, therefore, be subjected to external scrutiny more often. Dividend payments also reduce a firm's free cash flow, which imposes extra discipline on use of internal funds, thereby reducing wasteful expenditures. Norwegian firms should have lower agency costs since owner-managers face more of the wealth effects of their decisions (see Holder et al. [1998]), whilst the presence of large external shareholders is also likely to reduce agency costs, see Shleifer and Vishny (1986) and Allen et al. (2000). Hence the motivation to use dividends to reduce agency costs is weaker in Norway than in the U.S. or the U.K. Although corporate ownership renders dividends less important in reducing agency costs, if outside investors are important for the formation of share prices, dividends may have a signaling role to play. ${ }^{5}$

Ownership structure may also affect the extent of information asymmetry between managers and the external stock market. La Porta et al. (1999) report that, at the end of $1995,100 \%$ of firms were widely held in the U.K., $80 \%$ in the U.S., but only $25 \%$ in Norway. ${ }^{6}$ Together with significant family and state involvement, the ownership structure in Norway may curtail the amount of value relevant information that is

3. The degree of inside ownership in the U.K. and U.S. is less than the Norwegian market. The ownership by financial institutions is much more significant in the U.K. and U.S.

4. Norwegian firms also have a high degree of ownership by government and regional municipalities (approximately 17\%), significant ownership by foreign investors (approximately 29\%) and around 20\% of ownership by other Norwegian firms (Norwegian Registry of Securities, 1999). We do not have data on the ownership breakdown of individual firms for our sample.

5. Thanks to an anonymous reviewer who made this valid point.

6. This result is based on the 20 largest firms in each country. A similar result is reported for medium sized firms. 
available to external users. The quality of financial disclosure is also a factor. According to Ali and Hwang (2000) accounting data is less value relevant in: (i) bank oriented countries, (ii) countries where the private sector is not involved in the setting of accounting standards, (iii) countries where accounting practices follow the continental model, (iv) countries where tax rules have a greater influence on accounting measurement, and, (v) countries where spending on audit services is low. Norway fits all of these categories whereas none apply to the U.S. or the U.K. Hence the need to signal information to the market by other means, such as dividends, is more apparent in Norway.

Taxation is often thought to be influential in dividend signaling theory. The personal taxation of dividends make it a costly signal, and invariably more costly than the alternative of share repurchases. A more costly signal should convey a stronger management conviction to the market, and such signals are more difficult to replicate by inferior firms (John and Williams, 1985). Share repurchases, however, are not generally an option in Norway (Bohern et al. [1997]), so managers are not faced with a clear choice between a cheaper and a more costly signaling mechanism.

The neutrality of the tax system in Norway further implies that tax has little influence over the firm's chosen dividend policy. La Porta et al. (2000) devise a 'dividend tax advantage' metric where a rating of 1.0 is equivalent to tax neutrality. Norway's rating of 1.08 indicates a very marginal dividend tax advantage whilst the U.S. rating of 0.58 indicates an extreme tax disadvantage to dividends (the figure for the U.K. is 0.83 ). In any event, they find no conclusive evidence on the effect of taxes on dividend policies. The evidence linking tax with signaling models is also inconclusive (see Allen and Michaely [2003] for a summary), and some research findings are not consistent with the theory. For example, Amihud and Murgia (1997) study Germany where there is a tax advantage to dividends and find that the stock market reaction to dividend announcements is similar to U.S. studies where dividends are tax disadvantaged, implying that 'inexpensive' dividends also convey information to the market. Hence, there are good reasons to believe that the neutrality of taxation in Norway will not deter the use of dividends as a signaling mechanism.

For a number of reasons, therefore, Norway provides a suitable environment in which to test the signaling theory of dividends. The motivation to use dividends as a signaling mechanism is stronger in Norway due to the implications of the corporate ownership structure 
both for agency costs and for the extent of information asymmetry between managers and external shareholders. The relatively simple system of dividend payments and the neutral tax system in Norway should help minimize any 'noise' in the results due to those factors. In the light of the scant support based on U.S. research, evidence of a signaling theory explanation of dividends in Norway would suggest that corporate ownership structure is an important influence on the dividend policies of firms.

We test for evidence of the signaling theory in two stages. Firstly, we examine the stock market reaction to unexpected dividend changes to assess whether this is consistent with signaling theory. As an agency cost explanation is less likely in Norway, a market reaction in the same direction as the dividend change suggests that dividend announcements convey information to the market about the future prospects of the firm. Secondly, we investigate whether dividend increases are followed by permanent cash flow increases, as evidence in this respect would strengthen the empirical case for a signaling theory explanation of dividends.

The following null hypotheses are tested:

\section{Hypothesis 1}

H0: Dividend announcements do not provide information to the market; i.e., there is no stock price reaction on the announcement day.

Hypothesis 2

H0: Positive changes in dividends are not followed by permanent cash flow increases.

\section{Data and Testing Methods}

\section{A. Data}

The data were drawn from Datastream, Worldscope, FTExtel, financial statements, and the Amadeus database at the Norwegian School of Economics and Business Administration. The requirement for data on share price and dividend announcements provided a final sample of 64 
TABLE 1. Sample Descriptive Characteristics

\begin{tabular}{|c|c|c|c|}
\hline \multicolumn{4}{|l|}{ Panel A- Industry sector } \\
\hline Industry classification & & No of firms & $\%$ of firms \\
\hline Property & & 2 & $3 \%$ \\
\hline Finance & & 6 & $10 \%$ \\
\hline Manufacturing & & 27 & $42 \%$ \\
\hline IT/Communication & & 4 & $6 \%$ \\
\hline Media/Publishing & & 2 & $3 \%$ \\
\hline Offshore & & 5 & $8 \%$ \\
\hline Shipping & & 15 & $23 \%$ \\
\hline Transport & & 2 & $3 \%$ \\
\hline Others & & 1 & $2 \%$ \\
\hline Total & & 64 & $100 \%$ \\
\hline \multicolumn{4}{|c|}{ Panel B - Size at the beginning and end of the sample period } \\
\hline Years & Mean & Median & $\begin{array}{l}\text { Standard } \\
\text { deviation }\end{array}$ \\
\hline 1993 & 2,323 & 1,358 & 3,753 \\
\hline 1998 & 2,975 & 1,569 & 3,465 \\
\hline
\end{tabular}

Note: Industry sectors are based on the Oslo Stock Exchange Industry Classification. Finance includes all commercial banks, financial and insurance firms. Shipping and offshore firms are shown separately due to their prominence in the Norwegian economy. Size is determined by market value at the beginning and end of sampling period. Market values are taken from Datastream International and are expressed in millions of Norwegian Krona. The total market capitalization in 1993 was 210 billion krona and in 1998352 billion krona. Our initial sample represents $71 \%$ of the market capitalization of the firms on the Norwegian main list in 1993 and 69\% in 1998.

firms over the period 1993-98. To eliminate survivorship bias we did not require that a firm was in operation for the full sample period. Data prior to 1993 was not used, as the tax regulation was reformed in 1992. Descriptive statistics on the sample are provided in table 1 . The final sample was found to be a good proxy for the overall OSE market in terms of the distribution by industry (table 1, panel A) and by size over the period of the study (table 1, panel B).

Dividend announcement dates and payment amounts were obtained from FTExtel. Over the six-year period for our 64 firms there were 201 dividend announcements. Announcement dates were checked on the Amadeus database and announced dividend amounts were checked 
TABLE 2. Dividend Announcements

\begin{tabular}{|c|c|c|}
\hline \multicolumn{3}{|c|}{ Panel A-Sample } \\
\hline \multicolumn{2}{|c|}{ Industry classification } & No of firms \\
\hline \multicolumn{2}{|c|}{ Initial sample from FTExtel } & 201 \\
\hline \multicolumn{2}{|c|}{$\begin{array}{l}\text { Not comparable with Amadeus database for announcement } \\
\text { date or Datastream for payment amount }\end{array}$} & 12 \\
\hline \multicolumn{2}{|c|}{ Confounding events } & 33 \\
\hline \multicolumn{2}{|c|}{ Total sample } & 156 \\
\hline \multicolumn{3}{|c|}{ Panel B - Dividend announcements by year } \\
\hline Years & No of announcements & $\%$ of Total \\
\hline 1993 & 11 & $7 \%$ \\
\hline 1994 & 19 & $12 \%$ \\
\hline 1995 & 22 & $14 \%$ \\
\hline 1996 & 33 & $21 \%$ \\
\hline 1997 & 39 & $26 \%$ \\
\hline 1998 & 32 & $20 \%$ \\
\hline All years & 156 & $100 \%$ \\
\hline
\end{tabular}

Note: We compared the announcement dates from FTExtel with the Amadeus database at the Norwegian School of Economics and Business Administration. Any dates that were not confirmed were removed from the sample. Any dividend announcements with any confounding events on the FTExtel database in the 20 day period surrounding the announcement were also removed.

against the subsequent dividend payments logged on Datastream International. Non-verified observations were excluded. Observations with confounding events (such as share issues, bond issues, mergers, fund raising but excluding the announcement of results/earnings) in the 20-day period surrounding the dividend announcements were also eliminated. These additional criteria reduced the sample of dividend announcements to 156 (64 firms), as shown in panel A of table 2. Panel $B$ shows that our sample has more dividend announcements in the later years as the FTExtel increased its coverage of firm announcements from 1995 onwards. Nevertheless, no single year has more than $26 \%$ of the sample. We do not have annual dividend announcement data for all 64 firms in every sample year but the majority of firms paid regular dividends, particularly in the later years. Shares are placed in portfolios depending on whether dividend announcements are positive, negative or neutral (no change). 


\section{B. Testing Methods}

The market model is used to measure risk adjusted returns. The average $\mathrm{R}^{2}$ value for our sample is $19.78 \%$. Each security was required to have at least 15 non-missing returns in the event period and no missing returns in the five pre- and post-announcement days. If non-synchronous trading is allowed, daily excess returns can exhibit serial dependence; see Brown and Warner (1985). Dimson (1979) demonstrates that non-synchronous trading causes the OLS regression estimates of market model parameters to be biased and inconsistent. Securities were therefore required to have at least 80 non-missing returns in the estimation period. We use an estimation period of 250 days (-261:-11) and an event window of 21 days $(-10:+10)$, all relative to the dividend announcement day 0. A 21-day event window is selected to observe any effects prior to or after the announcement day, and to determine whether the market reacts efficiently to the announcement.

To determine whether there was asymmetry in the distribution of returns, tests of skewness and kurtosis were performed on our sample data. ${ }^{7}$ We use log-normal returns to reduce any bias resulting from skewness. ${ }^{8}$ Company returns and market returns for the OSE index were collected from Datastream International. We use t-tests when comparing means of the AAR of each of our samples and chi-squared $\left(\chi^{2}\right)$ tests for differences in the numbers of our various classifications/categories.

\section{Dividend Expectation and Portfolio Selection}

To examine the impact of unexpected dividend announcements on stock returns, a measure of expected dividend is required. We employ two alternative models of expected dividend; firstly, the naive 'no change' expectations model of Aharony and Swary (1980) and, secondly, a model based on analysts' forecasts. The 'analyst' model is discussed in section $\mathrm{V}$ below. The naive model is justified by the assertion that managers do not change dividends unless they expect a significant

7. For our sample the average skewness coefficient was 0.245 which implies that the distribution has a long right tail. The kurtosis was 7.414 which implies that the distribution is peaked.

8. As an additional check against the potential problems introduced by thin trading we also calculated abnormal returns using the market adjusted model. This model did not produce significantly different results from the results presented in section V. Tables are available from the authors on request. 
TABLE 3. Announcement Portfolios

\begin{tabular}{lrr}
\hline Portfolio & Number & \% of Total \\
\hline Positive & 87 & $56 \%$ \\
Negative & 19 & $12 \%$ \\
Neutral & 50 & $32 \%$ \\
Total & 156 & $100 \%$ \\
\hline
\end{tabular}

Note: The selection process and classification are made according to the naive expectations model, $E\left(D_{i, t}\right)=D_{i, t-1}$, where the dividend is expected to be equal to the previous years dividend for each period. Based on the deviation from expected dividend, dividend announcements were classified as releasing positive, negative or no information (neutral).

change in the future prospects of the firm. Investors therefore expect the dividend to be equal to the previous year's dividend, and changes are interpreted as a changes in management's expectations. The naive model of expected dividend is defined in equation (1).

$$
E\left(D_{i, t}\right)=D_{i, t-1}
$$

where $E\left(D_{i, t}\right)$ is the expected dividend per share for firm $i$ in year $t$ and $D_{i, t-1}$ is the dividend per share for the firm in year $t-1$.

Dividend announcements are classified as releasing positive, negative, or no information according to whether they are above, below or equal to the expected dividend. Table 3 reports 87 announcements of positive dividend changes, 50 with no change, and 19 negative changes for our 64 firms.

\section{Results}

Table 4 presents the results for the positive dividend announcements. There is a significant abnormal stock return on the announcement day of $0.76 \%$, (t-value $=4.29$, significant at the $1 \%$ level $)$. The market reaction implies increases in dividends release positive information about the firm. Hypothesis 1 is therefore rejected for positive dividend announcements. The magnitude of the share price reaction is small, limiting its economic significance, and the result is similar to several 
TABLE 4. Positive Dividend Announcements

\begin{tabular}{crccc}
\hline $\begin{array}{l}\text { Days } \\
\text { around AD }\end{array}$ & AAR & t-value & CAAR & t-value \\
\hline-10 & -0.0039 & $-2.17^{*}$ & -0.0039 & -2.17 \\
-9 & 0.0034 & 1.92 & -0.0005 & -0.08 \\
-8 & -0.0014 & -0.79 & -0.0019 & -0.61 \\
-7 & -0.0003 & -0.16 & -0.0021 & -0.60 \\
-6 & -0.0004 & -0.21 & -0.0025 & -0.63 \\
-5 & -0.0004 & -0.25 & -0.0030 & -0.68 \\
-4 & -0.0007 & -0.37 & -0.0036 & -0.77 \\
-3 & 0.0016 & 0.90 & -0.0020 & -0.40 \\
-2 & 0.0031 & 1.76 & 0.0011 & 0.21 \\
-1 & 0.0024 & 1.36 & 0.0036 & 0.63 \\
AD & 0.0076 & $4.29 * *$ & 0.0112 & 1.90 \\
1 & -0.0026 & -1.49 & 0.0085 & 1.39 \\
2 & 0.0021 & 1.19 & 0.0107 & 1.66 \\
3 & -0.0004 & -0.20 & 0.0103 & 1.55 \\
4 & 0.0022 & 1.22 & 0.0125 & 1.81 \\
5 & 0.0009 & 0.51 & 0.0134 & 1.88 \\
6 & 0.0037 & $2.06^{*}$ & 0.0170 & $2.32^{* *}$ \\
7 & 0.0000 & 0.02 & 0.0171 & $2.26^{*}$ \\
8 & 0.0000 & -0.02 & 0.0170 & $2.20^{*}$ \\
9 & -0.0007 & -0.37 & 0.0164 & $2.06^{*}$ \\
10 & 0.0002 & 0.09 & 0.0165 & $2.03^{*}$ \\
\hline
\end{tabular}

Note: AD is the dividend announcement date. AAR is the average abnormal return. CARR is the cumulative average abnormal return. t-values are the t-statistics for AAR or CARR $(\mathrm{N}=87)$. The selection process and classification are according to the naive expectations model. Daily returns are calculated from the market model. *denotes significance at the $5 \%$ level. $* *$ denotes significance at the $1 \%$ level.

U.S. studies referred to in DeAngelo et al. (1996) who state “...these studies typically find an average share price increase of the order of $1 \%$ or less." (p. 344). Over the 21-day event period of this study the CAAR of $1.65 \%$ is significant at the $5 \%$ level. The results do not suggest that signaling theory is stronger in Norway than in the U.S..

The results for negative dividend announcements are presented in table 5. There is a significant negative abnormal return of $-0.95 \%$ on the announcement day, (t-value $=-2.25$, significant at $1 \%$ level). Hypothesis 1 is therefore rejected, as dividend decreases release negative information to the market. The CAAR is negative on the announcement day and declines to $-1.7 \%$ by the tenth day over the twenty day period, 
TABLE 5. Negative Dividend Announcements

\begin{tabular}{rrrrr}
\hline $\begin{array}{l}\text { Days } \\
\text { Around AD }\end{array}$ & AAR & t-value & CAAR & t-value \\
\hline-10 & 0.0034 & 0.81 & 0.0034 & 0.81 \\
-9 & 0.0023 & 0.54 & 0.0057 & 0.95 \\
-8 & 0.0028 & 0.66 & 0.0085 & 1.16 \\
-7 & -0.0010 & -0.23 & 0.0075 & 0.89 \\
-6 & -0.0025 & -0.59 & 0.0050 & 0.53 \\
-5 & -0.0090 & $-2.14 * *$ & -0.0040 & -0.39 \\
-4 & 0.0064 & 1.53 & 0.0024 & 0.22 \\
-3 & 0.0006 & 0.13 & 0.0030 & 0.25 \\
-2 & -0.0009 & -0.22 & 0.0021 & 0.16 \\
-1 & 0.0036 & 0.85 & 0.0057 & 0.43 \\
$\mathrm{AD}$ & -0.0095 & $-2.25 * *$ & -0.0038 & -0.27 \\
1 & -0.0018 & -0.44 & -0.0056 & -0.39 \\
2 & 0.0037 & 0.89 & -0.0019 & -0.12 \\
3 & -0.0037 & -0.87 & -0.0056 & -0.35 \\
4 & 0.0010 & 0.25 & -0.0045 & -0.28 \\
5 & 0.0033 & 0.78 & -0.0012 & -0.07 \\
6 & -0.0010 & -0.23 & -0.0022 & -0.13 \\
7 & -0.0036 & -0.86 & -0.0059 & -0.33 \\
8 & -0.0039 & -0.93 & -0.0098 & -0.53 \\
9 & -0.0049 & -1.16 & -0.0147 & -0.78 \\
10 & -0.0023 & -0.55 & -0.0170 & -0.88 \\
\hline
\end{tabular}

Note: AD is the dividend announcement date. AAR is the average abnormal return. CARR is the cumulative average abnormal return. t-values are the t-statistics for AAR or CARR $(\mathrm{N}=19)$. The selection process and classification are according to the naive expectations model. Daily returns are calculated from the market model. *denotes significance at the $5 \%$ level. $* *$ denotes significance at the $1 \%$ level.

but it is not statistically significant. The negative announcement effects are also comparable with the findings of previous research although, as with the positive announcements, the results derived here are of a smaller magnitude. The market response to bad news is usually more pronounced the greater the extent of information asymmetry, but this does not appear to be the case in Norway.

Overall, these results indicate significant market reactions on the announcement date to positive and negative dividend changes. Whilst these results are consistent with signaling theory they are no stronger than the results reported for U.S. research.

The neutral announcement portfolio results are presented in table 6 . 
TABLE 6. Neutral Dividend Announcements

\begin{tabular}{rrrrr}
\hline $\begin{array}{l}\text { Days } \\
\text { Around AD }\end{array}$ & AAR & t-value & CAAR & t-value \\
\hline-10 & -0.9002 & -0.96 & -0.9002 & -0.96 \\
-9 & 0.9000 & 0.90 & -0.9002 & -0.94 \\
-8 & -0.9029 & -.87 & -0.9031 & -0.54 \\
-7 & 0.9003 & 0.10 & -0.9028 & -0.41 \\
-6 & 0.9026 & 0.76 & -0.9002 & -0.93 \\
-5 & -0.9056 & -1.64 & -0.9058 & -0.70 \\
-4 & 0.9018 & 0.54 & -0.9040 & -0.44 \\
-3 & -0.9014 & -0.41 & -0.9054 & -0.56 \\
-2 & -0.9017 & -0.51 & -0.9071 & -0.70 \\
-1 & -0.9007 & -0.22 & -0.9078 & -0.73 \\
$\mathrm{AD}$ & -0.9063 & -1.86 & -0.9141 & -1.26 \\
1 & -0.9030 & -0.89 & -0.9171 & -1.46 \\
2 & 0.9012 & 0.37 & -0.9159 & -1.30 \\
3 & 0.9018 & 0.53 & -0.9141 & -1.11 \\
4 & -0.9047 & -1.40 & -0.9188 & -1.44 \\
5 & 0.9037 & 1.10 & -0.9151 & -1.11 \\
6 & -0.9028 & -0.83 & -0.9179 & -1.28 \\
7 & 0.9090 & $2.66 * *$ & -0.9089 & -0.62 \\
8 & 0.9017 & 0.49 & -0.9072 & -0.49 \\
9 & -0.9028 & -0.83 & -0.9100 & -0.66 \\
10 & -0.9066 & -1.95 & -0.9166 & -1.97 \\
\hline
\end{tabular}

Note: AD is the dividend announcement date. AAR is the average abnormal return. CARR is the cumulative average abnormal return. t-values are the t-statistics for AAR or CARR $(\mathrm{N}=50)$. The selection process and classification are according to the naive expectations model. Daily returns are calculated from the market model. *denotes significance at the $5 \%$ level. $* *$ denotes significance at the $1 \%$ level.

Hypothesis 1 could not be rejected for this portfolio. No statistically significant share price reaction is observed on the announcement date implying that neutral announcements do not convey any new information. ${ }^{9}$ The neutral portfolio is, however, characterized by negative abnormal returns in the event period. The CAAR is $-1.66 \%$ for the 21 days of the event period, although not statistically significant. The negative AAR associated with the neutral announcement could be explained if, in fact, the market expects some decline in dividends, but

9. There is a significant un-explainable positive abnormal return on day +7 of $0.9 \%$. 
TABLE 7. Magnitude of Dividend Change

Panel A- Descriptive statistics of size of dividend change due to announcement

$\begin{array}{ll}\text { Positive dividend } & \text { Negative dividend } \\ (\% \text { change, } \mathrm{N}=87) & (\% \text { change, } \mathrm{N}=19)\end{array}$

\begin{tabular}{lrr}
\hline Mean & $33 \%$ & $-28 \%$ \\
Median & $25 \%$ & $-37 \%$ \\
Standard deviation & $30 \%$ & $25 \%$ \\
\hline
\end{tabular}

Panel B - Abnormal stock return on dividend announcement date

\begin{tabular}{llllr} 
& Positive & N & Negative & N \\
\hline Dividend change above median & 0.0102 & 43 & -0.0679 & 10 \\
Dividend change below median & 0.0054 & 44 & $\begin{array}{l}-0.1245 \\
-1.93^{*}\end{array}$ & 9 \\
t-value for difference in AARs & $2.34^{* *}$ & & & \\
\hline
\end{tabular}

Note: We compare the AAR on the announcement date for dividend changes above and below the median for both the positive and negative change portfolios. (For the positive portfolio the median breakpoint was $25 \%$ and for the negative portfolio it was $-37 \%$ ). AAR is higher for positive dividend changes that are above the median, and AAR is higher for negative changes that are below the median (ie more negative). Test of differences are based on $\mathrm{t} \#$ tests when comparing means of AAR. *denotes significance at the $5 \%$ level. **denotes significance at the $1 \%$ level.

the naive model does not capture this. ${ }^{10}$

Brickley (1983) has shown that the size of the dividend change is important in explaining the share price reaction. For our portfolios of positive and negative dividend announcements we form two sub-samples split at the median level of dividend change. We then compare the average abnormal returns for these sub-samples on the announcement date. Table 7 panel A illustrates the magnitude of the dividend change for both the positive and negative dividend announcements and shows that the increase in dividend is on average larger than the decrease, although the median is lower. Panel B of table 7 shows that the market reaction is stronger for larger dividend changes,

10. Although some significant abnormal returns were found subsequent to the announcement day these were found on day +7 , and from some checks of the data it seems to be the result of extreme observations. The negative trend in the neutral Norwegian portfolio suggests that there might be some bias present in the data sample. No efforts were made to correct for beta bias, from thinly traded stock, as this would reduce the sample significantly; see Solibakke (2000) for a discussion of thinly traded stocks in the Norwegian market. 
TABLE 8. Year by year analysis

Panel A - Dividend announcements by year

\begin{tabular}{lrrrr} 
Years & Positive & Negative & \multicolumn{1}{l}{ Neutral } & Total \\
\hline 1993 & $4(36 \%)$ & $2(19 \%)$ & $5(45 \%)$ & 11 \\
1994 & $10(53 \%)$ & $3(15 \%)$ & $6(32 \%)$ & 19 \\
1995 & $10(53 \%)$ & $4(18 \%)$ & $8(36 \%)$ & 22 \\
1996 & $17(51 \%)$ & $5(15 \%)$ & $11(33 \%)$ & 33 \\
1997 & $26(67 \%)$ & $0(0 \%)$ & $13(33 \%)$ & 39 \\
1998 & $20(62 \%)$ & $5(16 \%)$ & $7(22 \%)$ & 32 \\
All years & $87(56 \%)$ & $19(32 \%)$ & $50(32 \%)$ & 156 \\
\hline
\end{tabular}

Panel B - AARs on announcement date

\begin{tabular}{lccc} 
Years & Positive & Negative & Neutral \\
\hline Years 1993-95 & & 9 & 19 \\
$\mathrm{~N}$ & 24 & -0.0096 & -0.0056 \\
AAR & 0.0089 & $(2.20)^{*}$ & $(-1.68)$ \\
Years 1996-98 & $(2.59)^{* *}$ & 10 & 31 \\
$\mathrm{~N}$ & 63 & -0.0087 & -0.0068 \\
ARR & 0.0079 & $(2.09)$ & $(-1.88)$ \\
t-values for & $(2.13)^{* *}$ & $(0.43)$ & $(0.32)$ \\
differences in AAR & $(0.20)$ & & \\
\hline
\end{tabular}

Note: In panel A, $\chi^{2}$ tests test for differences between the numbers of positive, negative and neutral dividend announcements between the years $\chi^{2}=9.937,10$ degrees of freedom, $p$ - value $=0.55$. AARs are average abnormal return; their $\mathrm{t}$-values are in parentheses. The mean AARs are compared for three portfolios of dividend announcements classified as positive, negative and neutral using the naive expectations model for our sample split between the early years 1993-95 and the later years 1996-98. *denotes significance at the 5\% level. $* *$ denotes significance at the $1 \%$ level.

both positive and negative, implying they send a stronger signal.

We also tested for consistency across the years of the study, 1993-1998. Table 8 panel A, shows that there is no significant difference in the numbers of positive, negative and neutral dividend announcements between the years $\chi^{2}=9.937,10$ degrees of freedom, $p$-value $=0.55$ ). The low numbers of dividend announcements in the early years of our sample precludes a rigorous year by year analysis. Therefore we compare the first three years of the sample with the last three years. The results in table 8 panel B imply the market reaction is 
not time specific as there is no significant difference between the sub-periods and the total sample period.

\section{Robustness Tests}

\section{A. Alternative Method for Identifying Unanticipated Dividend Changes}

The naive model may not fully capture the impact of a dividend announcement, especially as investors' expectations are influenced by information throughout the year. Therefore, we also consider dividend forecasts made by financial analysts as these should reflect all the available information at the time of the forecasts. Expected dividend is specified as:

$$
E\left(D_{i, t}\right)=\overline{A F}_{, t}
$$

where $E\left(D_{i, t}\right)$ is the expected dividend per share for firm $i$ in year $t$. and $\overline{A F}_{i, t}$ is the average analysts' forecast of dividend per share for the firm in year $t$.

The average analysts' forecasts were collected from the Norwegian School of Economics and Business Administration and were available for 45 dividend announcements in our sample (for 35 companies). Announcements are classified into portfolios according to how they deviate from the analysts' average forecasts, providing 14 positive announcements, 24 no change announcements and 7 negative announcements. The majority of the dividend announcements are now neutral which could indicate the analyst model provides more up to date forecasts than the naive model (chi-squared tests show significant differences in the numbers of positive, negative and neutral announcements in the two models, $\chi^{2}=8.8304,2$ degrees of freedom, $p$-value $=0.02$ ). Despite this, we found that the classifications of dividend announcements generated from the analyst model as positive, neutral and negative were the same as the naive model for $36(82 \%)$ of the dividend announcements ( 10 for positive, 6 for negative and 20 for no change). This finding provides some support for our earlier results based on the naive expectations model.

Panel A of table 9 reports the AAR for the analyst model on the announcement day (we do not provide the results for \pm 10 days as these 
TABLE 9. Alternative Analyst Model

Panel A- Average abnormal returns

\begin{tabular}{lccc} 
& Positive & Negative & Neutral \\
\hline $\mathrm{N}$ & 14 & 7 & 24 \\
$\mathrm{AAR}$ & 0.0122 & -0.046 & -0.040 \\
$\mathrm{t}-$ value & $2.72 * *$ & -0.77 & -1.29 \\
\hline
\end{tabular}

Panel B - Abnormal stock return on dividend announcement

\begin{tabular}{lccc} 
& Positive & Negative & Neutral \\
\hline $\mathrm{N}$ & 87 & 19 & 50 \\
Naive model & 0.076 & -0.0095 & -0.063 \\
$\mathrm{~N}$ & 14 & 7 & 24 \\
Analysts model & 0.0122 & -0.046 & -0.040 \\
t-value & $2.18^{* *}$ & -1.40 & -0.32 \\
\hline
\end{tabular}

Note: Average abnormal returns (AAR) and t-statistics are shown for positive, negative and neutral dividend announcements using portfolios determined by the analyst model. Abnormal returns are calculated using the market model adjusted to log-normal returns. We do not present the results for the \pm 10 days around $\mathrm{AD}$, but these are available upon request. *denotes significance at the $5 \%$ level. **denotes significance at the $1 \%$ level.

were not significantly different from the naive model). Consistent with the naive model, the positive portfolio had a significant AAR on the announcement day whilst the neutral portfolio did not. However, the announcement day AAR for the negative portfolio is now insignificant, probably due to the small number of events in this portfolio. The difference between the naive and analyst models is only significant for positive dividend announcements (see table 9, panel B). The positive market reaction is greater for firms whose dividend exceeds the analysts' prediction, implying that these provide the most information.

\section{B. Dividend Increases and Cash Flows}

Overall, the results on the market reaction to dividend announcements in Norway, as reported in tables 4 to 9 , are consistent with signaling theory. Whilst we have argued that an agency explanation is less likely in Norway, a second test is necessary to confirm a signaling theory explanation. We therefore test hypothesis 2 to ascertain whether positive dividend announcements signal permanent changes in the future 
TABLE 10. Cash Flow Analysis

Panel A - Positive dividend announcements and subsequent cash flows

\begin{tabular}{lcr} 
& Number & $\%$ of Total \\
\hline Permanent increase & 24 & $31 \%$ \\
temporary increase & 16 & $28 \%$ \\
No increase & 37 & $48 \%$ \\
Total & 77 & $100 \%$ \\
\hline
\end{tabular}

Panel B - Average abnormal returns on announcement day

\begin{tabular}{llll} 
& $\mathrm{N}$ & ARR & t-value \\
\hline Permanent increase & 24 & 0.0125 & $2.62^{* *}$ \\
temporary increase & 16 & 0.067 & 1.77 \\
No increase & 37 & 0.078 & $2.19^{*}$ \\
\hline
\end{tabular}

Panel C - Differences between average abnormal returns of cash flow portfolios

\begin{tabular}{llll} 
& $\mathrm{N}$ & ARR & t-value \\
\hline Permanent increase & 24 & 0.0125 & $2.10^{* *}$ \\
temporary increase & 16 & 0.067 & 0.45 \\
No increase & 37 & 0.078 & $1.79^{*}$ \\
\hline
\end{tabular}

Note: 87 positive dividend announcements were considered based on the naive expectations model for the 64 sample firms during 1993-98. Data were not available for 6 firms reducing the number of announcements to 77 . The 'permanent increase' sample has four years of cash flow each at least $30 \%$ higher than the year of the dividend announcement. The 'temporary increase' sample has cash flows $40 \%$ higher in the year following the dividend announcement but no more than $20 \%$ higher in either years 2 or 3 . The 'no increase' sample has four years of flat cash flows following the year of the dividend announcement. Cash flow is defined as operating income less interest and taxes per share normalized by cash flow in the year of the dividend announcement. Cash flow data between 1994 and 2002 were obtained from Worldscope Global Access/FTExtel. AAR is the average abnormal return for positive announcements using portfolios determined by the subsequent cash flow profile of the positive dividend announcing firm. Daily returns and event period abnormal returns are calculated using the market model adjusted to log-normal returns. In panel $\mathrm{C}$ we compare the mean abnormal return on the dividend announcement date for our three portfolios of positive dividend announcements using the naive expectations model classified according to their subsequent four years cash flow as permanent, temporary and no cash flow. Tests of differences are based on t\#tests when comparing means of AAR each sample against the other two samples. *denotes significance at the $5 \%$ level. **denotes significance at the $1 \%$ level.

cash flows of the firm. Brook et al. (1998) found that U.S. firms that are 
about to experience large, permanent cash flow increases following four years of stable cash flows announce higher dividends, and generate large significant abnormal stock market returns. Our sample size of 64 firms does not permit the imposition of a similar constraint on prior cash flows, and we consider the time series of dividend announcements between 1993 and 1998 rather than take a cross sectional approach. However, we adopt their approach in considering the pattern of cash flows in the four years following our 87 positive dividend announcements. We employ a measure of operating cash flow per share, defined as operating income before extraordinary items and depreciation less interest and taxes, normalized by cash flow in the year of the dividend announcement. Data for 1994-2002 were obtained from Worldscope Global Access/FTExtel (four years data after the sample period were required). We group dividend announcements into three categories based on the cash flow profile used in Brook et al. (1998). That is, (a) Permanent increase: the cash flows in the four subsequent years remain at least $30 \%$ above the cash flow in the positive dividend announcement year, (b) Temporary increase: the cash flow in the year after the positive dividend announcement is $40 \%$ above the cash flow in the year of the dividend announcement but falls to less than $20 \%$ higher in years 2, 3 and/or 4 and (c) No increase: the cash flow increase is less than $30 \%$ in total between the year of the dividend increase and the subsequent 4 years, and by less than $15 \%$ in each of these years. We also include in this sub-sample any firm whose cash flow declined following the positive dividend announcement.

The results in panel A of table 10 show that $52 \%$ of firms experienced either a permanent or temporary increase in cash flows in the four years following the positive dividend announcement. Our results are not as strong as Brook et al. (1998) in suggesting that firms signal large and permanent cash flow increases when they raise their dividends. This result may be due to our inability to impose the stable cash flow restriction on the sample prior to the positive dividend announcement, and/or our use of multiple dividend announcements for the same firms and/or the strict definition of permanent cash flows for four years. ${ }^{11}$

11. When we relax the strict assumption of permanent cash flow increases and look at the cash flows patterns before and after the positive dividend announcements we do find evidence that the cash flows following positive dividend changes are higher than the pre dividend cash flows. However, this test has problems as our sample is cross sectional and therefore we were considering in some cases the same firms' cash flow patterns for different 
The results in panel $\mathrm{B}$ of table 10 show a significantly positive stock market reaction for firms that subsequently experienced permanent cash flow increases, and also for firms with no cash flow increase. There is an insignificant positive reaction for firms with temporary cash flow increases. The magnitude of the AAR is greatest for firms with permanent cash flow increases, and this is statistically significantly greater than the AAR for firms with temporary or no cash flow increases (table 10 panel $\mathrm{C}$ ).

On the basis of this evidence we cannot unambiguously reject Hypothesis 2 that positive dividend changes are not followed by permanent cash flow increases. It appears that Norwegian managers do not use positive dividend announcements solely to signal permanent cash flow increases. However, the market correctly discriminates between positive dividend changes followed by permanent cash flow improvements and those positive announcements with any other subsequent cash flow profile. The positive market reaction to dividend increases is consistent with dividend changes containing useful information but in some cases are not signals of a future permanent cash flow increase. In these cases they may convey positive information about current or recent performance to confirm management's view that current good performance is not transitory. Allen and Michaely (2003) suggest that existing empirical tests are not able to distinguish between these alternative interpretations, and we have the same problem. Miller (1987) argued that (empirically) dividends are better described as lagging rather than leading earnings, whilst Grullon et al. (2002) suggest that dividends may be used to signal a change in the firm's risk. Both are possible explanations of our mixed results.

Overall the evidence presented here offers modest support for the signaling theory of dividends but it is no more compelling than the reported evidence for the U.S. market, despite the notable differences in ownership structures. Ownership structure does not, therefore, appear to be an important factor in motivating managers to use dividends as a signaling mechanism.

\section{Interaction with Earnings Announcements}

An enduring problem when testing the information content of dividends is the proximity of dividends and earnings announcements (see, Baker,

dividend announcements. 
TABLE 11. Alternative Analyst Model

Panel A- AARs for dividend announcements without earnings announcements

\begin{tabular}{lccc} 
& Positive & Negative & Neutral \\
\hline $\mathrm{N}$ & 19 & 9 & 17 \\
$\mathrm{AAR}$ & 0.0096 & -0.0079 & -0.0029 \\
t-value & $(2.78)^{* *}$ & $(-2.02)^{*}$ & $(-0.92)$ \\
\hline
\end{tabular}

Panel B - Dividend announcement and the related earnings announcement

Dividend announcements

\begin{tabular}{|c|c|c|c|c|}
\hline \multirow{2}{*}{$\begin{array}{l}\text { Earnings } \\
\text { announcements }\end{array}$} & \\
\hline & Positive & Negative & Neutral & Total \\
\hline Positive & $46(53 \%)$ & $3(16 \%)$ & $23(46 \%)$ & 72 \\
\hline Negative & $15(17 \%)$ & $7(37 \%)$ & $9(18 \%)$ & 31 \\
\hline Neutral & $26(30 \%)$ & $9(47 \%)$ & $18(36 \%)$ & 53 \\
\hline Total & 87 & 19 & 50 & 156 \\
\hline
\end{tabular}

Panel C - AARs and their t-values for dividend/earnings portfolios

\begin{tabular}{lccc}
\multirow{2}{*}{$\begin{array}{l}\text { Earnings } \\
\text { announcements }\end{array}$} & \multicolumn{2}{l}{ Dividend announcements } \\
\cline { 2 - 4 } & Positive & Negative & Neutral \\
\hline Positive & 0.0079 & 0.0065 & 0.0085 \\
& $(-2.61)^{* *}$ & $(1.89)$ & $(3.23)^{* *}$ \\
Negative & - & -0.0110 & -0.0089 \\
& - & $(-2.36)^{* *}$ & $(-2.04)^{* *}$ \\
Neutral & -0.0021 & -0.0062 & -0.0069 \\
& $(-0.61)$ & $(-1.49)$ & $(-1.70)$ \\
\hline
\end{tabular}

Note AAR is for average abnormal return. Parentheses in panels A and C include the t-values for AARs. Positive, negative and neutral dividend announcements using portfolios determined by the naïve expectations model are shown. The earnings surprise as positive, negative and neutral is defined by a model of the change in earnings per share of firm i from time $(t-1)$ to time $t$, the dividend announcement date (or closest date to the dividend announcement date.*denotes significance at the 5\% level. **denotes significance at the $1 \%$ level.

1999). Earnings figures are generally released during the same period as dividends are declared. Stock price adjustments could be due to either or both of these announcements. Using FTExtel, we found that for $71 \%$ (111) of our sample, dividends and earnings were announced on the same day. For the remaining $29 \%$ (45) of dividend announcements we 
repeated our analysis of the share price reaction. The 45 announcements (for 30 companies) were split into portfolios of positive, negative and neutral according to the naive expectations model, providing 19 positive, 9 negative and, 17 neutral announcements. As the abbreviated results in panel A of table 11 are similar to those reported in tables 4, 5 and 6, our findings on dividend announcements are robust to the impact of concurrent earnings announcements.

Nevertheless, even for these 45 dividend announcements the majority of the earnings announcements occurred within a one-month period of the dividend announcements. The impact of the earnings announcement could still influence the results for market reaction to the dividend announcements for this group so an additional test was carried out. We grouped our total sample of dividend announcements into categories associated with positive, negative or neutral earnings surprises. We use a naive earnings expectation model similar to the naive dividend expectations model to define our earnings surprise, as $\triangle E P S_{i, t}$, that is the change in earnings per share of firm $I$ from time $(t-1)$ to time $t$, where $t$ is the dividend announcement date. The earnings announcement date closest to $t$ is used in the analysis.

For our sample of 156 dividend announcements $46 \%$ of the firms had positive earnings increases and only $20 \%$ had earnings decreases. Panel B of table 11 shows all the possible combinations of dividend and earnings announcements. There is a significant difference in the breakdown of positive, negative and neutral dividend announcements and the related earnings announcements (chi-squared tests show significant differences between the various dividend/earnings portfolios $\chi^{2}=9.2835,4$ degrees of freedom, $p$-value $=0.06$ ). Over half of the positive dividend announcements were accompanied by a positive earnings announcement and very few were combined with negative earnings. Also, few negative dividend announcements were accompanied by positive earnings surprises. For the neutral dividend announcements there was no defined pattern. We tested for any significant difference between the market reactions to dividend announcements when they are classified according to the accompanying earnings release. The results in panel $\mathrm{C}$ of table 11 shows there are no particular dividend/earnings combinations that have significantly different AARs on the announcement date when compared with the findings for dividend announcements alone as reported in tables 4, 5, and 6. Positive (negative) AAR accompanies all positive (negative) dividend announcements, irrespective of the associated earnings 
announcements. Neutral dividend announcements have no significant AAR for any of the earnings announcement portfolios. Whilst there is no significant difference between any of the dividend/earnings combinations for each category of dividend announcements, there was a larger market reaction to negative dividend announcements combined with negative earnings announcements, and for neutral dividend announcements combined with negative earnings. Hence we are confident that our overall findings on the market reaction to dividend announcements are robust.

\section{Conclusions}

This study investigates the dividend signaling hypothesis by examining the stock market reaction to dividend announcements on the Oslo Stock Exchange (OSE). The ownership structure in Norway, with its implications for agency costs and information asymmetry, increases the likelihood of a signaling theory explanation of dividends. Significant abnormal stock price returns are present on the announcement day for both the positive and negative portfolios of dividend announcements whilst neutral announcements are associated with insignificant negative returns. The market reaction is greater the larger the change in dividend.

There is no significant difference in our results using a dividend expectations model based on analysts' predictions, and our results are robust to the possible confounding effects when dividend and earnings announcements occur close together.

The most significant market reactions occur for positive dividend announcements that are followed by permanent cash flow increases, and this is supportive of signaling theory. However, positive dividend announcements do not always signal permanent cash flow increases so our evidence does not provide unequivocal support of the signaling theory of dividends. An alternative explanation is that dividends convey positive information about current or recent performance but, as other research papers have also found, the existing empirical tests are not able to distinguish between the alternative interpretations.

Overall the results of this study support the first stage of the signaling hypothesis that announced changes in dividends convey information to the market, but the evidence on subsequent cash flows is less strong. The findings are of particular interest given the distinct differences in corporate ownership characteristics between Norway and 
the U.S., where the majority of the previous research has taken place. Our results, however, are no stronger than those found in U.S. research, implying that ownership structure is not an important influence on firms' use of dividends. More specifically, the evidence from Norway suggests that lower agency costs and greater information asymmetry do not increase the likelihood that managers will use dividends as a signaling mechanism.

\section{References}

Ali, A., and Hwang, L. 2000. Country specific factors related to financial reporting and the value relevance of accounting data. Journal of Accounting Research 38: 1-21.

Aharony, J., and Swary, I. 1980. Quarterly dividend and earnings announcements and stockholder returns: an empirical analysis. Journal of Finance 35: 1-12.

Allen, F.; Bernardo, A. E.; and Welch, I. 2000. A theory of dividends based on tax clientele. Journal of Finance 5: 2499-2536.

Allen, F., and Michaely, R. 2003. Payout Policies. In G. Constantinedes, M. Harris, and R. Stulz. Handbook of the Economics of Finance, North-Holland. (forthcoming).

Amihud, Y., and Murgia, M. 1997. Dividends, taxes and signaling: Evidence from Germany. Journal of Finance 52:397-408.

Baker, H. K. 1999. Dividend policy issues in regulated and unregulated firms: A managerial perspective. Managerial Finance 25: 1-20.

Benartzi, S.; Grullon, G.; Michaely, R.; and Thaler, R. 2002. Changes in dividends (still) signal the past. Working paper. Cornell University.

Bhattacharya, S. 1979. Imperfect information, dividend policy, and the "bird in the hand" fallacy. Bell Journal of Economics 10: 259-270.

Bohern, O.; Haug, J.; and Michalsen, D. 1997. Consolidation policy and managerial discretion: Accounting for intercorporate shareholdings. Research report. Norwegian School of Management.

Brickley, J. 1983. Shareholder wealth, information signaling, and the specially designated dividend: An empirical study. Journal of Financial Economics 12: 187-209.

Brook, Y.; Charlton, W. T.; and Hendershott, R. J. 1998. Do firms use dividends to signal large future cash flow increases? Financial Management 27: 46-57.

Brown, J., and Warner, J. 1985. Using daily stock returns: The case of event studies. Journal of Financial Economics 14: 3-31.

DeAngelo, H.; DeAngelo, L.; and Skinner, D. J. 1996. Reversal of fortune: Dividend signaling and the disappearance of sustained earnings growth. 
Journal of Financial Economics 40: 341-371.

Dimson, E. 1979. Risk measurement when shares are subject to infrequent trading, Journal of Financial Economics 7: 197-226.

Grullon, G.; Michaely, R.; and Swaminathan, B. 2002. Are dividend changes a sign of firm maturity? Journal of Business 75: 387-424.

Holder, M. E.; Langreher, F. W.; and Hexter, J. L. 1998. Dividend policy determinants: An investigation of the influences of stakeholder theory. Financial Management 27: 73-82.

John, K. and Williams, J. 1985. Dividends, dilution, and taxes: A signaling equilibrium. Journal of Finance 40: 1053-1070.

Koch, P. D., and Shenoy, C. 1999. The information content of dividends and capital structure policies. Financial Management 28: 16-35.

La Porta, R.; Lopez-de-Silanes, F.; and Shleifer, A. 1999. Corporate ownership around the world. Journal of Finance 54: 471-517.

La Porta, R.; Lopez-de-Silanes, F.; Shleifer, A.; and Vishny, R. W. 2000. Agency problems and dividend policies around the world. Journal of Finance 55: 1-33.

Miller, M. 1987. The information content of dividends. In J. Bossons, R. Dornbush and S. Fischer (Eds) Macroeconomics: Essays in Honor of Franco Modigliani. MIT Press, Cambridge, MA.

Norwegian Registry of Securities. 1999. Norwegian Company Statistics.

Oslo Stock Exchange. 1998. Dividends in companies listed on the Oslo Stock Exchange. Statistics from the Oslo Stock Exchange. Research Department Oslo Bourse, Number 3.

Pettit, R. R. 1972. Dividend announcements, security performance and capital market efficiency. Journal of Finance 5: 993-1007.

Prowse, S. 1995. Corporate governance in an international perspective: A survey of corporate control mechanisms among large firms in the U.S., U.K., Japan and Germany. Financial Markets, Institutions and Instruments 4:1-63.

Shleifer, A., and Vishney, R. 1986. Large shareholders and corporate control. Journal of Political Economy 94: 461-488.

Solibakke, P. B. 2000. Stock return volatility in thinly traded markets: An empirical analysis of trading and non-trading processes for individual stocks in the Norwegian thinly traded equity market. Applied Financial Economics 10: 299-310. 
